\title{
Investigation of Grammatical Cohesive Devices Errors Made by Saudi EFL Students in Written Paragraphs: A Case Study of the University of Tabuk, Saudi Arabia
}

\author{
Dr. Ahmed Khider Ahmed Othman
}

Department of English Language and Translation,

Faculty of Education and Arts, University of Tabuk, Saudi Arabia

\begin{abstract}
A good paragraph must be as clear as possible so that the reader can follow sentences, ideas, and details easily. The purpose of this study is to investigate the types, frequencies, and causes of grammatical cohesive devices errors in the written paragraphs which were committed by the Saudi Englishmajor students (male) who are majoring in English language at the Department of Language and Translation at the University of Tabuk in Saudi Arabia. 40 paragraphs were selected randomly from second year first term mid-exams in the year 2018-2019. A mixed design method of both qualitative and quantitative research methodology was used to analyze the participants' written texts. To analyze the data, a framework by Halliday and Hassan (1976) was adopted. The result of the study showed that the three major types of cohesive devices errors (reference, substitution, and conjunction) were found in the students' written paragraphs. Hence, they were used in dealing with errors in texts. The most frequently occurred errors were conjunction with the percentage of $52 \%$, reference $37 \%$, and substitution $11 \%$. The findings showed that the Saudi undergraduates committed these kinds of errors due to lack of inadequate grammatical knowledge of these devices, influence of mother tongue interference, lack of vocabulary, and language background. The study recommends that grammatical cohesive devices should be taught explicitly, as well as in association with reading skill, in developing grammatical cohesive devices awareness.
\end{abstract}

Keywords: EFL writing, cohesion, cohesive device errors, paragraph

\section{Introduction}

Writing is one of the most important language skills in teaching English as a foreign language (EFL). It is the second productive skill besides 
speaking. Through communication, developing the writing skill is considered to be highly complex in each aspect that leads to some of the troubles faced by EFL students (Khelifij, 2014).

According to Tangermoon (2008), "Learning to write is not just a question of developing a set of mechanical orthographic skills: it also involves a new set of cognitive and social relations" (Tribble, 1996, p.12). In fact, writing is perceived to be a major challenge to many learners, especially learners whose native language is not English. According to Byrne (1988, p.1), "when we write we use graphic symbol; that is we combine letters that represent our sound when we speak, and these letters are combined to form words, and words to form sentences". Crystal (2006, p257) stated that "writing is a way of communicating which uses visual marks made on some kind of surface; it is one of graphic expressions" (cited in Azzioui, 2009).

Paragraph in academic writing has basic definition and crucial detail as a group of sentences that are linked together for discussing one idea. The number of sentences within a paragraph is often between five and ten sentences. This, however, depends on the topic itself. Savage and Mayer (2006, p13) defined a paragraph as "a group of sentences about a topic. A typical paragraph begins with a topic sentence, which introduces the topic. The supporting sentences follow the support idea in the topic sentence with explanations, reasons, and other details. The concluding sentence brings the paragraph to an end". This means a paragraph should be cohesive enough to achieve cohesion over these written texts.

Halliday and Hasan (1976) identify five types of cohesion: reference, substitution, ellipsis, lexical, and conjunction. The first three types fall under the category of grammatical cohesion. Lexical cohesion, on the other hand, refers to relations between any lexical items. Conjunctive cohesions are affected by the cohesion elements that are called conjunctives. Conjunctions are considered as grammatical devices with a lexical component. According to Halliday and Hasan, the presence of these cohesive devices is essential for building text cohesion. Cohesion and coherence are very problematic area for EFL learners.

In EFL context, writing is the most difficult skill to master. Saudi students of English find it very difficult to construct a coherent written paragraph in English. The difficulties lie not only in the poor organization, the inappropriate thesis statement, the inadequacy of providing examples and details and the limited vocabulary, but also on the misuse of cohesive devices. Cohesion and coherence are considered as the two important features of good writing. Therefore, this paper focuses on grammatical cohesive devices errors made by Saudi EFL students in written paragraphs at University of Tabuk. 


\section{Literature Review}

A number of studies focusing on cohesive devices have been conducted in different countries where English is taught as a foreign language. Researchers have given considerable attention to how EFL learners write and the problems they are faced with. Some came up with similar findings while others have been contradictory. One of the related studies on the grammatical cohesive devices written by EFL learners is the study of Alzankawi (2017) which was conducted to investigate Kuwaiti undergraduate students of English and their attitudes towards the writing process, particularly the characteristics of cohesion and quality. The main objective of the study was to concentrate on dealing with the macro level cohesive devices in students' descriptive English writing. The analysis also revealed that the correlation coefficient between writing scores and reference cohesive device is positive and statistically significant, since only the reference cohesive device was highly correlated with score.

In Saudi Arabia, Saud (2015) conducted a study on cohesive devices using a descriptive composition written by Saudi University Students majoring in English. Halliday and Hassan's (1976) model was selected as the most comprehensive framework for the analysis of the cohesive features in the student's writing. Analysis of the data consisted of investigating the relationship of these devices with scores of writing. The findings reveal that "Good students" used more cohesive devices in their writings compared to weak students.

Similarly, Salim and Mudwi (2015) investigated the effectiveness of using cohesive devices and writing strategies in developing EFL learners' writing skills. The sample of this study comprised of (100) first years students who study English at SUST. On one hand, the results have revealed that the experimental group encountered difficulties in using cohesive devices in writing skills. On the other hand, the control group performed slightly better.

Likewise, Anwar (2017) explored cohesive devices on the abstracts of undergraduate thesis written by English Language Teaching Department Students of IAIN Syekh Nurjati Cirebon. This study aims to find out the types of cohesive devices that are commonly used on the abstracts, and also focuses on describing the usage of cohesive devices on the abstract. The results show that several cohesive devices found on undergraduate thesis abstracts includes grammatical and lexical cohesion.

Also, Rahman (2017) examined the use of grammatical cohesion on students' academic essay writing in the 4th Semester of English Language Department of Ibnu Khaldun University, Bogor. The objective of this study is to know the types of grammatical cohesive features, the frequent types of grammatical cohesive features, the appropriate and inappropriate used of grammatical cohesive features, and the errors committed by the students in cohesive writing. The findings showed that reference $(56.3 \%)$ was the 
predominant of grammatical cohesive features used by the students in academic essay writing compared to other types. Meanwhile, substitution $(0.5 \%)$ was the least one.

In Korea, Cho (2014) investigated cohesive devices in English writing textbooks and Korean college students' writings through text and corpus analyses. This study also analyzed the frequencies of sentence transitions and demonstratives in learner and native speaker corpora. The results revealed L2 learners' tendency to overuse sentence transitions and demonstrative pronouns compared to native speakers. However, the results also show that as proficiency increases, learners tend to use fewer sentence transitions.

Moreover, Hendrayana (2012) analyzed the cohesive devices used in the narrative paragraph written by the fifth semester students of English Department at the University of Muhammadiyah Malang. The aim of this study was to know the types of cohesive devices that occurred in the students' narrative paragraph and the most dominant of the type of cohesive devices used in the students' narrative paragraph. The result of this study showed that three major types from five major types of cohesive devices were found in the students' narrative paragraph. They were reference, conjunction, and lexical cohesion. Substitution and ellipsis were not found in the students' narrative paragraph.

In Libya, Elbarani (2012) examined the challenges that fourth year university students face when writing an English paragraph, particularly in the areas that is related to writing and developing a topic sentence. The results of the study showed that the students exhibited a low level of creativity and accuracy when writing in their L2, particularly when developing a topic sentence.

In Saudi Arabia, Wahby (2014) conducted a study at Taibah University on the effect of implementing cohesive devices by Saud prep- year pre intermediate students on their written texts. Based on findings, the study showed that students who had better cohesive knowledge, and who were more trained on using cohesive ties, appropriately, employed well-organized cohesive texts.

Kargozari et al. (2012) conducted a study to investigate the use of cohesive devices in 180 compositions (argumentative, descriptive, and expository) written by Iranian EFL university students. Results indicated that the lexical devices were used most in the student's writing followed by references and conjunctions. Moreover, certain problems such as misuse, overuse, and restriction of reference, conjunction, and lexical devices were identified in the students' compositions.

This study is different from the above-mentioned studies because it focuses on grammatical cohesive devices errors made by Saudi EFL students in written paragraphs at University of Tabuk. 


\section{Statement of the Problem}

Saudi students at the Department of Language and Translation at the University of Tabuk face difficulties in producing well-connected paragraphs. However, these problems mainly indicate that students fail in their academic register when it comes to writing, low proficiency in vocabulary use, incoherent paragraph, as well as misuse of lexical items. The researcher as an English language instructor noticed that students are likely to use long sentences and they fail to use punctuation which results in creating ambiguous statements and obstruct the clarity of messages. These reasons have been the main motive for the researcher to conduct this study. Hence, this study investigates grammatical cohesive devices errors made by Saudi EFL students in written paragraphs at the University of Tabuk.

\section{Research Objectives}

This study intends to address the following objectives:-

- To identify the types of grammatical cohesive devices errors employed by Saudi EFL Students in written paragraphs.

- To find out the most frequent grammatical cohesive devices errors in students' written paragraphs.

- To find out the causes of the most common grammatical cohesive devices errors used by Saudi EFL students' written paragraphs.

\section{Research Questions}

In order to achieve the research objectives, this study addresses the following research questions:

1. What are the types of grammatical cohesive devices errors employed by Saudi EFL students in written paragraphs?

2. What is the most frequent category of grammatical cohesive devices errors used by Saudi EFL students in written paragraphs?

3. What are the causes of the most common grammatical cohesive devices errors used by Saudi EFL students in their written paragraphs?

\section{Research Methodology}

This qualitative-quantitative study investigates cohesive devices errors made by Saudi EFL students in their written paragraphs at the English Language and Translation Department at the University of Tabuk. The quantitative analysis of the cohesive errors is regarded as a perquisite for the qualitative analysis which is used to describe errors made by the subject of the study. In addition, it is also used to identify types, reasons, and frequencies of errors. However, the analysis was confined to the cohesive devices errors which are mainly reference, substitution, and conjunction. That is to say, other kinds of errors are not taken into account. Halliday and Hassan's (1976) model 
was adopted as the most comprehensive framework for the analysis of the cohesive errors in students' writing. 40 paragraphs samples were collected randomly from first term mid-exam in year 2018-2019. These exams were done by second year undergraduate students from Tabuk University, English Language and Translation Department, Saudi Arabia. The subjects are similar in terms of their age, ranging from 19-22 years. They are also homogenous in regards to nationality, native language (Arabic), language proficiency, and educational background.

\section{Discussions and Findings}

This current study investigated 40 undergraduates Saudi EFL students at the Department of Language and Translation at the University of Tabuk. The objective of the study was to investigate the types, frequencies, and causes of grammatical cohesive errors. The tables and figures below show the analysis in terms of frequency and percentage of every category of error. Table 1 presents the percentage of grammatical cohesive errors in written paragraphs. It shows the frequency and percentage of reference, substitution, and conjunction errors. This is illustrated from the table and the chart below.

Table 1. The percentage of grammatical cohesive errors committed by Saudi EFL

\begin{tabular}{|c|c|c|}
\hline Category & Frequency & Percentage \\
\hline i. Errors of reference & 46 & $37 \%$ \\
\hline ii. Errors of substitution & 14 & $11 \%$ \\
\hline iii. Errors of conjunction & 65 & $52 \%$ \\
\hline Total Errors & 125 & $100 \%$ \\
\hline
\end{tabular}

As shown in Table 1 above, it is realized that errors of conjunction in students' written paragraphs recorded 65 frequencies in producing about $52 \%$ of the whole errors in written paragraphs. Furthermore, errors of reference reported 46 making about $37 \%$ of the overall errors. Besides, errors of substitution frequented 14 in producing $11 \%$ of the total of errors. Figure 1 in the next section displays the percentage of grammatical cohesive devices which were committed by students in written paragraphs (N-40). It shows the percentage and frequency of errors of reference, substitution, and conjunction. 
Figure 1. The percentage of grammatical cohesive devices errors in written paragraphs $(\mathrm{N}-$ 40)

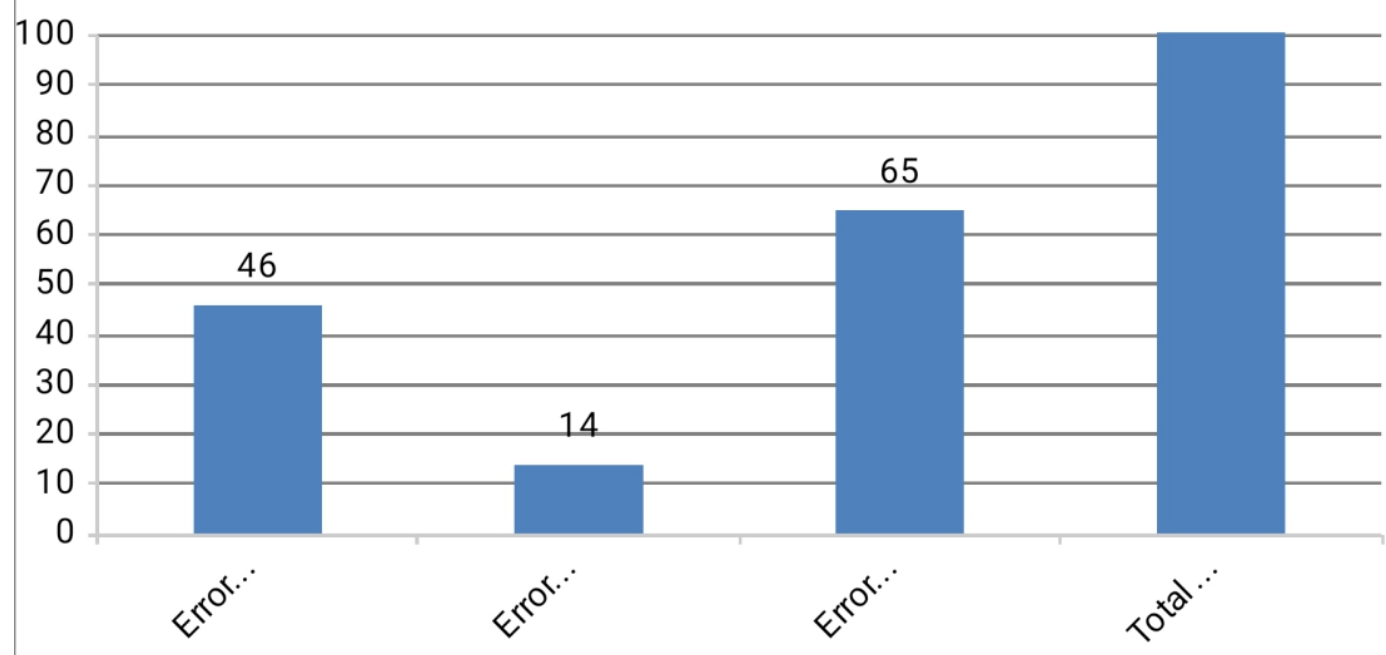

Figure 1 above reflects the percentage of grammatical cohesive devices errors which students made in written paragraphs. Each percentage was calculated in relation to the total number of errors in forty paragraphs. Most of the errors committed in using conjunction which frequented 65 times recorded $52 \%$, whereas the reference errors frequented 45 times recording $37 \%$. The errors of substitution frequented 14 times recording $11 \%$ from the total sample of errors. Table 1 and Figure 1 provide the answer to the first and second questions. The quantitative analysis shows that the students committed three types of grammatical cohesive errors in their written paragraphs; such as reference, substitution, and conjunction errors. In response to the second research question, the results of the study revealed that the most frequent of all errors was conjunction followed by reference errors. On the other hand, the least errors made were substitution errors. Table 1, 2, and 3 display the cohesive sub-devices in Students' written paragraphs.

Table 2. The percentage of reference cohesive sub-devices errors in written paragraphs

\begin{tabular}{|c|c|c|}
\hline Sub-devices & Frequency & Percentage \\
\hline i. Personal & 25 & $55 \%$ \\
\hline ii. Demonstrative & 13 & $28 \%$ \\
\hline iii. Comparative & 8 & $17 \%$ \\
\hline
\end{tabular}

As displayed in Table 2 above, personal sub-devices errors recorded 25 frequencies in producing about $55 \%$ of the whole from reference errors. Besides, demonstrative sub-devices errors scored 13 making about $28 \%$ of the whole errors. Furthermore, comparative sub-devices errors frequented 8 in producing $17 \%$ of the total errors. These sub-devices errors are found to be the highest percentage of all errors committed by Saudi EFL students. Then, 
personal, demonstrative, and comparative errors were the second highest. Table 3 reflects the percentage of substitution cohesive sub-devices errors in students' written paragraphs.

Table 3. The percentage of substitution cohesive sub-devices errors in written paragraphs

\begin{tabular}{|c|c|c|}
\hline Sub-devices & Frequency & Percentage \\
\hline Nominal & 4 & $28 \%$ \\
\hline Verbal & 3 & $21 \%$ \\
\hline Clausal & 7 & $50 \%$ \\
\hline
\end{tabular}

As depicted in Table 3 above, clausal sub-devices errors recorded 7 frequencies producing about 50\% overall from reference errors. Moreover, nominal sub-devices errors scored 4 making it about $28 \%$ of the total number of errors. Also, verbal sub-devices and clausal errors recorded 3 producing $21 \%$ of the total errors. However, sub-devices errors were found to be the highest percentage of error which was committed by Saudi EFL students. After then, this was followed by nominal and verbal errors. Table 4 reflects the percentage of conjunctive cohesive sub-devices errors in students' written paragraphs.

Table 4. The percentage of conjunctive cohesive sub-devices errors in written paragraphs

\begin{tabular}{|c|c|c|}
\hline Sub-devices & Frequency & Percentage \\
\hline Adversative & 20 & $31 \%$ \\
\hline Additive & 25 & $38 \%$ \\
\hline Temporal & 12 & $18 \%$ \\
\hline Clausal & 8 & $12 \%$ \\
\hline
\end{tabular}

As revealed in Table 4 above, additive sub-devices errors occurred 25 times recording $38 \%$, whereas adversative frequented 20 times recording $31 \%$. Besides, it is followed by temporal errors frequented 12 times recording $18 \%$. The clausal sub-device errors occurred 8 times, which recorded $12 \%$ from the total of conjunctive sub-devices errors. The highest frequent errors committed by students were additive and the least ones were clausal. In response to question three, most of the students committed such kinds of errors because of the inadequate grammatical knowledge of these devices, influence of mother tongue interference, lack of vocabulary, and language background.

\section{Conclusion}

In conclusion, the present research was designed to provide answers to the research questions in meeting the research objectives. Halliday and Hasan's (1976) cohesion framework was adopted to investigate grammatical cohesive devices errors made by Saudi EFL Students in written paragraphs at University of Tabuk, Saudi Arabia. The data of the study was quantitatively and qualitatively analyzed by identifying the types, the frequency as well as the causes of cohesive devices used by the participants, and by evaluating the 
overall quality of the students' written paragraphs. Due to the results presented in the current research, there was a notable difference in the students' use of cohesive devices in terms of frequency and variety. Students overused, misused, and omitted certain types of cohesive devices (reference, substitution, and conjunction) while neglecting to use the others. The researcher noticed that the results of the study show that undergraduate Saudi committed these kinds of errors due to lack of students' inadequate grammatical knowledge of these devices, influence of mother tongue interference, lack of vocabulary, and language background. The researcher recommends that grammatical cohesive devices should be taught explicitly, as well as in association with reading skill, in developing grammatical cohesive devices awareness.

\section{References:}

1. Alzankawi, M. (2017). Kuwaiti Undergraduate Problems with Cohesion in EFL Writing. International Journal of Education, Learning and Development. Vol. 5, No.4 pp.55-65.

2. Anwar, M. (2017). Exploring Cohesive Devices on the Abstracts of Undergraduate Thesis Written by English Language Teaching Department Students of IAIN Syekh Nurjati Cirebon. A thesis for undergraduate degree; Retrieved from https://core.ac.uk/download/pdf/147421194.pdf.

3. Azzioui, A. (2009). The dissertation of' teaching writing through the process approach". Mentoury University. Constantine.

4. Byrne, D. (1988). Teaching Writing Skills. London Longman Press.

5. Cho, H.Y. (2014). Cohesive Devices in English Writing Textbooks and Korean Learners' English Writings: English Teaching, Vol. 69, No. $1, \mathrm{~S}$.

6. Crystal, D. (1995). The Cambridge Encyclopedia of the English Language, CUP.

7. Elbarani, E.W. (2012). Investigating Some Problems Encountered by Fourth Year Students in the English Department at the University of Benghazi in Developing the Topic Sentence. M.A Dissertation. University of Benghazi.

8. Hendrayana, R. (2012). An Analysis of Cohesive Devices used in the Narrative Paragraph Written by the Fifth Semester Students of English Department in in University of Muhammadi Yahmalang. Ph.D. Dissertation: Retrieved fromeprints.umm.ac.id/...jiptummb-rezaandika-28084-1-pendahul-n.p.

9. Halliday, M.A.K. \& Hasan, R. (1976). Cohesion in English. London: Longman. 
10. Khelfji, W. (2014). The Use of Cohesive Devices in Paragraph Writing Case study: Second Year LMD Students at Biskra University, Algeria . MA dissertation in language science: Retrieved from dspace.univbiskra.dz:8080/jspui/bitstream/123456789/8574/1/a2.pdf.

11. Kargozari, R. et al. (2012). Cohesive Devices in Argumentative, Descriptive, and Expository Writing Produced by Iranian EFL University Students: Modern Journal of Language Teaching Methods. 2(3).

12. Rahman, T. (2017). Investigation of Grammatical Cohesion on Students' Academic Essay Writing. Faculty of Tarbiya and Teachers' Training, State Islamic University. Jakarta M.A Thesis: Retrieved from

http://repository.uinjkt.ac.id/dspace/bitstream/123456789/36480/1/T HESIS.

13. Savage, A. \& Shafeil, M. (2006). Effective academic writing: the paragraph. Oxford. University press.

14. Salim, S.Y. \& Mudwi, A.K. (2015). Investigating the use of cohesive devices in English as the second language writing skills. International Journal of Recent Scientific Research Vol.(6) 4, pp.34843487:available Online at http://www.recentscientific.com.

15. Saud, W.I. (2015). Cohesion in the Descriptive Writing of EFL Undergraduates: International Journal of Humanities and Cultural Studies. Retrieved from http://ijhcschiefeditor.wix.com/ijhcs.

16. Tangermoon, T. (2008). Integrated Approaches to Improve Students Writing Skills for English Major Students. ABAC Journal. V, 28, No.

17. Tribble, C. (1996). Writing. London. Oxford University Press.

18. Wahby, M. (2014). The effect of cohesive devices ties by Saudi prep year pre-intermediate students on written texts: European Scientific Journal Vol.10, No.4: 1857 - 788 